\title{
Study on the Legal Liability for Environmental Offences
}

\author{
Aleksey Fatyanov \\ Department of State and Legal and Criminal Law Disciplines \\ Plekhanov Russian University of Economics \\ Moscow, Russia \\ E-mail: 561712@mail.ru
}

\author{
Irina Rogaleva \\ Department of State and Legal and Criminal Law \\ Disciplines \\ Plekhanov Russian University of Economics \\ Moscow, Russia \\ E-mail: irina05_85@mail.ru \\ Alexander Bobkov \\ Department of Industrial Economics \\ Plekhanov Russian University of Economics \\ Moscow, Russia \\ E-mail: a.1.bobkov@gmail.com
}

\author{
Galina Rogaleva \\ Department of Labor Law and law of social security \\ Kutafin Moscow State Law University \\ Moscow, Russia \\ E-mail: g.a.semik@mail.ru
}

\begin{abstract}
The article is dedicated to one of the relevant problems in modern legal regulation in Russia - the absence of proper legal arrangements for environmental offences. The challenge lies in intersectorial, interdisciplinary regulation of the above mentioned social relations which suggests the existence of a comprehensive legal institution of environmental offences that includes civil, labour, criminal, economic, competitive and administrative law regulations. Intersectorial nature of the analyzed social relations results in fragmentarity and controversy of amendments introduced into legal acts.
\end{abstract}

Keywords—ecology; offences; liability; environmental safety; environment

\section{INTRODUCTION}

According to statistics, 14.13 thousand environmental crimes were registered in the Russian Federation in JanuaryJuly 2017 which is $5.5 \%$ less than over the same period last year [1]. These offences demonstrate a latent (concealed) character in our country. The Russian legislation often lacks certain mechanisms to impose environmental liability for petty offences compared to many countries in Europe, America and some Asian countries where an offender throwing litter on streets will at least pay a several thousand dollar fine. Enterprises that violated environmental protection legislation, in case of monitoring and oversight authority inspection may even need to stop production as in this case the law obliges them to shut down the enterprise [2].
The subject-matter is relevant today due to the fact that the problem of environmental safety in general and the rational use of natural resources has already existed for several years [3]; to our mind, the solution to this problem lies in rigorous compliance with the Russian environmental protection legislation. When examining cases on violations of environmental legislation, a full and comprehensive investigation of all the circumstances related to the wrongful act shall be performed in order to prevent unreasonable exemption of the offender from liability.

Environmental liability exists in a legal and ecologicaleconomic form and shall be considered as one of the types of legal liability.

Legal liability today is the state guarantee of incentives or constraints that are secured against legal standards, implemented through compliance with the law by participants in legal relations and legal liability of persons on compliance with and satisfaction of the requirements defined by legal standards, in case of violations, persons should bear adverse effects of personal or material nature.

In other words, legal liability needs to be considered as liability of a person who has committed a wrongful act to suffer adverse, penalizing effects.

Several characteristics of legal liability can be identified:

- the subject violates statutory legal provisions;

- legal liability is regulated by legal acts 
- violation of legal provisions as a negative reaction consists in the application of specified enforcement measures towards the offender, certain sanctions, their application being regulated by procedural rules and regulations.

Competent authorities implement state enforcement measures in a procedural form as ascertained by statute and may be of the following character: pecuniary (fine), organizational (disqualification) and also personal (imprisonment).

\section{GENERAL PROVISION ON LIABILITY FOR ENVIRONMENTAL OFFENCES}

Legal liability performs the following functions: educational, protective, reinstating justice and punitive.

The ecological-economic function consists in the following: both private persons and legal entities that inflicted damage to the environment as a result of their unlawful acts such as pollution, depletion, damage, destruction, irrational use of natural resources, deterioration and destruction of ecosystems, natural landscapes, natural constituents and other violations of legislation in terms of environmental protection in compliance with the law are obliged to compensate for it in full.

As for the natural environment, the inflicted damage may be expressed through real and estimated losses in the natural environment. These losses usually exist in the form of actual damage - real losses in the natural environment, for instance, the destruction of forests, fauna, depletion of waters, etc. and also in the form of material losses, i.e. expenses for the recovery of the disturbed natural environment [4], [5].

Environmental harm may be: a resource that is difficult to renew, a nonrenewable and renewable resource. Environmental harm, first of all, infringes on the constitutional human right to favorable and healthy environment that needs to be manifested through favorable conditions surrounding the society.

Liability for environmental offences envisaged by the existing legislation aims at the protection of social interests being one of the state enforcement forms. That is why it is implemented in compliance with the Russian legislation by specific authorized officials and state authorities also regulating the rules of environmental liability imposition.

Thus, it may be concluded that environmental liability is, first of all, an economic and legal body that combines standards and corresponding relations on the prevention of and compensation for harm inflicted to the natural environment and is expressed through the violation of legal provisions, negative reaction to an offence, implementation of specified enforcement measures towards the offender on behalf of officials and state authorities within their competence and in compliance with the Russian legislation.

An administrative type of liability is a more efficient legal liability imposed for the violation of environmental legislation. It is worth mentioning that administrative liability for an environmental offence has certain specific features [6] that are expressed through the object of the offense and is a means of law enforcement as well as an element of state and authoritative powers and one of the ways to strengthen legality in terms of natural resources exploitation and environmental protection. Such liability is reflected in procedural acts by imposition of administrative fine on the offender which is expressed through negative consequences and accompanied by the disfavor and reprimand of the person who has committed an offense.

An administrative offence that resulted in damage inflicted to a proprietor, human and the environment in general may entail liability. Administrative liability is applicable only in case of offences that are specified in the Code of the Russian Federation on Administrative Offences and in special statutory acts of industry-specific legislation.

\section{METHODS AND ORGANIZATION OF RESEARCH}

The authors seeking to contribute to the development of legal understanding of environmental offences identified the objective to present the system of legal regulations in the sphere of ecology focusing on debatable and controversial doctrinal and legal provisions.

To prove the specified hypothesis, the statistics of environmental crimes has been used.

The majority of environmental crimes have not been registered that is why there may be some fluctuations in numbers. Environmental crimes bear objective indicators that are impossible to hide: for example, the destruction of the ecosystem and nature, environmental pollution.

Public danger of environmental crimes consists, first of all, in the menace to vital activities.

Environmental crimes are often unpredictable. It is also explained by the limited capacities of science to fully discover cause-and-effect relations in biological and natural systems. The impact of chemical radiation, natural disasters and other factors on living bodies is hard to forecast. In this regard, the Criminal Code of the Russian Federation prohibits activities that can destroy the natural balance, have destructive effect on the environment, health and life of people.

The dynamics as well as the condition and the share, latency level and other quantitative and qualitative indicators of environmental crimes will be analyzed using official and scientific resources. Statistics says that in 2015 the number of environmental crimes registered in the Russian Federation amounted to 24728 crimes, in 2016 - 25450 crimes and in 2017 - 25489 crimes. However, the share of these environmental crimes in the total number of registered crimes increased from $0.3 \%$ in 2015 to $0.9 \%$ in 2016.

\section{RESUlTS AND DisCUSSION}

In our opinion, environmental crimes endanger environmental safety which in this case is their specific object. If ecological safety is qualified as such, then it coordinates with the essence of the generic object of crime, being this generic object, which complies with the contents 
of public safety that covers environmental safety as an independent type.

The article analyzes legal liability for environmental offences in different countries around the world. Compared to Russia, legal liability in other countries is tougher. For example, on January 21, 2000 as a result of pipeline rupture at Petrobras oil refinery 1.3 million liters of oil were released into the water in Guanabara Bay, Rio de Janeiro. This environmental disaster is considered one of the biggest in the history of the city. The company fully admitted their guilt and paid a fine of over $\$ 25$ million. These funds were used to restore the ecosystem in the Bay and compensate for losses incurred by people in the coastal region.

Then, in July 2000 an accident happened at Petrobras oil refining platform in the Brazilian state of Parana. More than million gallons of oil were released into the Iguazu River risking to poison potable water in several cities. Five barriers were built to liquidate the consequences of the accident. The company paid a $\$ 56$ million fine to the national budget and \$30 million - to the state budget. On April 20, 2010 there was an explosion on the Deepwater Horizon drilling rig owned by the Swiss company, Transocean Ltd., and rented by BP British Corporation, located not far from the shore of Louisiana in the Gulf of Mexico. The accident killed 11 people and injured 17 people; 4.9 million barrels of oil got into the Gulf waters and a 75 thousand square kilometers oil spill reached the coast of five US states. Both flora and fauna were damaged, fishing and travel companies incurred huge losses. In November 2012, BP admitted its guilt in 11 criminal charges that were brought by the U.S. Department of Justice. In January 2013, the parties reached a compromise - BP agreed to pay a fine to the US authorities amounting to $\$ 4.5$ billion and the U.S. Department of Justice dropped further charges. The company's total loss after the accident including expensed for liquidation of consequences equaled around $\$ 45$ billion. In February 2013, the court in New Orleans, Louisiana approved the agreement between Transocean Ltd and the U.S. Department of Justice under which the company was supposed to pay a fine of $\$ 1.4$ billion to the government. In July 2013, Halliburton, the American company, admitted guilt for installing equipment for cementation of subaqueous pipe on Deepwater Horizon. The company received the maximum fine which can be imposed in such cases which amounted to \$200 thousand. Moreover, it agreed to transfer \$55 million into the National Fish and Wildlife Foundation. In April 2014, the results of litigations conducted for many years by Anadarko Petroleum Corp., the energy company, were summarized. The company agreed to pay a record-breaking fine of $\$ 5.15$ billion to settle the claims of the U.S. Department of Justice and the Environmental Protection Agency. Charges for the pollution of soil, water and air were pressed against Kerr-McGee company established in 1929 and purchased by Anadarko in 2006. The agreement is to be approved by the US federal court [7].

The Criminal Code of the Russian Federation envisages liability for environmental offences (Chapter 26). For example, liability for the violation of environmental protection rules in the installation, design, construction, placing into operation and operations of industrial, agricultural, scientific or other objects by persons who are responsible for the compliance with such rules if it results in a significant change in the radiation level, harm inflicted to humans, mass mortality of animals or other heavy consequences is punishable by a fine of maximum 120000 rubles. Littering and pollution as well as depletion of surface and ground waters, potable water sources or other modification of their natural properties if these actions resulted in significant damage to flora and fauna, fish, forestry and agriculture are punishable by a fine of maximum 800000 rubles. Sea environment pollution from sources located on the shore or following violation of rules for burial or discharge from transport vehicles or artificial islands, installations or constructions of substances or materials that are harmful for humans and water biological resources or that prevent lawful use of sea environment is punishable with a fine of maximum 200000 rubles.

Administrative as well criminal liability for environmental offences exists in Russia [8]. Violations of water legislation that are qualified by us as administrative misdemeanors: violation of water resources conservation or water management rules as well as damage to aquicultural installations and constructions, violation of rules for their exploitation.

Administrative offences entail legal liability if they resulted in harm inflicted to a person or the environment.

According to the Code of the Russian Federation on Administrative Offences, forestry offences are as follows: damage or destruction in forests; illegal use of forests; violation of forest restoration and improvement rules, use of mature timber; damage of forests by chemical substances of harmful emissions, wastes; discharge of construction and household wastes in forests, destruction or damage of restriction signs in forests, violation of fire safety.

Violations of natural resources management are violations of rules and requirements for geological research works and rules for natural resource protection.

There are articles dedicated to the protection of fauna, i.e. those on the violation of rules for transportation, storage and use of plant protection agents and other agents that inflicted damage to fauna; rules for hunting, fishing as well as fish resources protection and other requirements for the utilization of fauna, on the destruction of engendered or rare animal species, other actions that harm fauna and their habitat. The Code of the Russian Federation on Administrative Offences contains articles on the violation of animal habitat protection rules, creation of zoological collections and their trade, unauthorized relocation of them as well as illegal import to the republican territory of plants and animals that harm the central flora and fauna.

Unauthorized deforestation, damage of soil and also water pollution is huge harm that is manifested through the infliction of damage to proprietary interests of natural resources proprietors which happens as a result of damage, destruction and depletion of natural resources. 
The Code of the Russian Federation on Administrative Offences doesn't contain a notion of "administrative environmental offence" which speaks about ambiguous interpretation of this term.

In order to specify grounds for administrative and legal liability, the object of administrative environmental offence needs to be specified first of all as the one playing an important role.

That is why borrowing best foreign practices and upgrading of environmental crimes penalties in Russia and also efficient use of state assets such as independent analytical activities including independent expertise in the form of specific assessment and analytical as well as scientific and research activities aimed at information and methodological support of decisions taken in the course of environmental management and provision of environmental safety are important steps in the solution of challenges[9].

\section{CONCLUSION}

Summarizing the research that has been carried out, we can make a conclusion that environmental liability is an economic and legal body that unites legal arrangements and regulates their standards in terms of compensation for damages inflicted to the environment manifested through the violation of substantive rights, negative reaction to the violation and the application of enforcement measure towards the offender that are stipulated in the legislation from the part of officials and state authorities within the limits of their competence and not contradicting the law. Among types of legal liability, administrative and criminal liability for environmental offences prevails.

In order to distinguish a criminal offence from an administrative offence, all signs of corpus delicti need to be thoroughly analyzed.

Such liability will apply to perpetrators for committed offences that are socially dangerous acts and are envisaged by the existing legislation. Compliance with environmental requirements and rules stimulates administrative enforcement actions.

Statutory legal acts that envisage liability for environmental offences, generally, are realized as formal constituent elements compared to those that envisage liability for environmental crimes. Such conditions are characteristic for both current administrative and criminal legislation. It was first of all selected to distinguish between environmental misdemeanors.

The current situation has actually only aggravated the problem in question. Standards that envisage environmental liability have a very complicated structure that is why crimes are difficult to assess. Today, methods for the assessment of environmental harm are being developed and the existing methods are based on the possibility to identify an economic equivalent.

On a "large scale", there are problems of establishing the causal connection between offence against nature and the consequences that followed.
Based on the above mentioned information, we understand that when an act has been defined in the Criminal Code of the Russian Federation and the Code of the Russian Federation on Administrative Offences in similar terms, the enforcer has two options to solve certain in environmental protection problems. In order to hold someone administratively liable for offence against natural environment (as component elements are usually formal) it will be enough to only establish the fact of a wrongdoing indicated in the law. Holding someone criminally liable is a more complicated path as both the wrongdoing and its consequences need to be established together with the causeand-effect relationship between them (as component elements of crimes are mainly material). In this case, the choice is obvious. It mostly explains why in real life, only four out of 18 articles of the Criminal Code of the Russian Federation that specify liability for environmental crimes are mainly implemented.

Not the least important, to our mind, is the efficiency of environmental crimes' prevention. In case of proper preventive measures, it would be important to consider the nature of offences and the reasons for them as well as their conditions. The reasons for both administrative and criminal environmental offences are weaknesses of moral, economic, educational and legal spheres. In case of organization and implementation of preventive measures, focus should be made on the short-term and long-term forecast of environmental situation. In our opinion, the development with people of certain sustainable ecological and legal conscious is an important preventive measure which should be developed at school including special events on the educational curriculum to develop children's environmental and legal conscious.

Compliance with environmental legislation requirements is complicated due to the fact that reasons for environmental offences should be prevented by timely elimination.

\section{REFERENCES}

[1] Official website of the Ministry of Internal Affairs of the Russian Federation URL:https://mvd.rf (access date 03.10.2017).

[2] Bogolyubov S.A. Ecological law.: A textbook. Moscow, 2014. P. 98.

[3] Ivlev V., Oseledchik M. Methodological principles for the introduction of modality categories in modern scientific cognition // 3rd international conference on arts, design and contemporary education (ICADCE 2017) Moscow, Russia, 29-30 мая 2017 г. General chairs: Alexandr Yakoupov, Xiaojie Wei, Olga Chistyakova, Galima Lukina, Oleg Filippov. 2017. P. 541-545.

[4] Tydeman K., Lutchman I. Report to H.M. Government of Gibraltar on "The Management of Marine Living Resources in the Waters around Gibraltar". H.M. Government of Gibraltar. Ministry for the Environment Duke of Kent House, Line Wall Road, Gibraltar. December, 2012. P. 5

[5] CRFM Strategic Plan (2013 - 2021) // CRFM Administrative Report. Belize and St. Vincente and the Grenadines. 2013. C. 7

[6] Salvatore A., Charlotte S. Bioprospecting of Genetic Pesources in the Deep Seabed: Scientific, Legal and Policy Aspect. UN University, Institute of Advanced Studies, June 2005. P. 10.

[7] http://tass.ru/info/1236951

[8] Savchina O.V., Savchina O.V., Bobkov A.L., Sharashidze A.Z. On the state of the mortgage market in the Russian federation in the 
conditions of global economic crisis // Journal of Applied Economic Sciences. 2016. T. 11. No. 6. C. 1096-1103.

[9] Trangott E. Fish, Fishing and Fisheries. Addressing Illegal, Unreported and Unregulated Fishing. New York. 2010. P. 3. 